\title{
Progresses of the Past Decade on Factors Contributing to Skeletal Muscle Glycogen Synthase Regulation
}

\section{Matthew Goff and Guoxun Chen*}

Department of Nutrition, University of Tennessee at Knoxville, Knoxville, Tennessee, USA

\begin{abstract}
Glycogen is the primary storage form of glucose, which is metabolized actively in the liver and skeletal muscle of mammals. The skeletal muscle glycogen is used intracellularly to provide starting substrate for glycolysis, whereas liver glycogen is used mainly for the maintenance of blood glucose homeostasis. The conversion of glucose to glycogen is an ordered process, in which the enzyme glycogen synthase plays an essential role. The key events in the synthesis of glycogen have been elucidated in both the liver and muscle. The process of understanding the regulatory mechanism of glycogen synthase activity has led to the discoveries of many important players in cellular metabolism. Research in identifying factors modulating muscle glycogen synthesis has been of popular interest within the past decade. The goal of this review is to summarize potential factors affecting skeletal muscle glycogen synthase expression level and activity in literatures published for the past decade.
\end{abstract}

Keywords: Glycogen; Glycogen synthase; Glycogen phosphorylase; Insulin; Metabolic disorders; Skeletal muscle

\section{Introduction}

The ability to acquire and store energy is essential for an organism to face environmental challenges such as the lack of readily available nutrients. Glycogen, the highly branched polysaccharide, serves as the primary storage form of glucose [1]. The liver and skeletal muscles are the major storage sites of glycogen in human body. As shown in Figure 1 , glycogen in the liver and skeletal muscle is used differently [2]. The role of glycogen within the skeletal muscle is to provide glucose for energy production while the primary role of glycogen in the liver is to supply glucose in the blood for the use in other tissues [2]. During the fed-state, the entry of dietary nutrients into the blood leads to the secretion of the anabolic hormone, insulin, from the pancreatic $\beta$-cells [2]. The activation of insulin signaling pathway increases the activities of enzymes involved in glycogenesis including Glycogen Synthase (GS), and in turn, enhance glycogenesis in hepatocytes and muscle cells $[3,4]$. During a fasting state, the entry of dietary nutrients into blood stops, and the pancreas reduces insulin and increases glucagon secretion, a process that reduces glycogenesis and enhances glycogenolysis [2]. GS and Glycogen Phosphorylase (GP) are primary enzymes for glycogenesis and glycogenlysis, respectively [5]. The hepatic glycogenolysis provides source of glucose to be released into the blood [5]. Unlike the liver, muscle lacks glucose-6-phosphatase activity which results in the use of glucose inside muscle cells [6].

The conversion of glucose to glycogen is an ordered process that has been studied extensively. UTP-glucose-1-phosphate uridylyltransferase catalyzes the conversion of glucose-1-phosphate to Uridine Diphosphate (UDP)-glucose in the expenditure of Uridine Triphosphate (UTP) [7]. At the core of the glycogen molecule is a protein homodimer known as glycogenin. Glycogenin has two tyrosine residues that will accept glucose moiety from UDP-glucose [3]. Therefore, glycogenin serves two roles in the process of glycogen synthesis: 1) the anchoring core molecule for glycogen formation, and 2) the initiating enzyme to begin the growing glycogen chain. UDP released from the reaction is recycled for the reformation of UTP. Glucose molecules are first linked by $a(1 \rightarrow 4)$ glycosidic bonds until the formation of a branch [3]. After roughly eight to ten glucose units have been linked via $\alpha(1 \rightarrow 4)$ glycosidic linkage, the enzyme GS takes over the elongation process. After the glycogen molecule grows in length, the glycogen branching enzyme will catalyze the transfer of a terminal fragment of six to ten glucose moieties from a non-reducing end to the C- 6 hydroxyl group of a glucose moiety closer to the interior of the glycogen molecule, forming an $\alpha(1 \rightarrow 6)$ glycosidic bond [7,8]. With the increase of branching points in glycogen particles, it allows more non-reducing end for hydrolysis by GP at the same time and increases particle's solubility, which helps more efficient glucose storage [8].

As shown in Figure 1, the activities of GS and GP are regulated covalently and allosterically. The activities of GS and GP are regulated in the liver and skeletal muscle covalently through phosphorylation and through allosteric effectors such as intracellular Glucose-6Phosphate (G6P) and ATP levels [4,9]. G6P can either be used to enter the glycolytic pathway or converted to Glucose-1-Phosphate (G1P) by phosphoglucomutase [7]. Intracellular increases in G6P will assist in the activation of GS and inactivation of GP, therefore, favoring glycogen synthesis [7]. During periods of elevated energy (ATP) levels, GP will remain dephosphorylated in favor of glycogen formation [10]. Within skeletal muscle, when Adenosine Monophosphate (AMP) levels rise due to factors such as exercise, GP is phosphorylated to promote the formation of G1P, which can then enter the glycolytic pathway [10].

Glycogenesis and glycogenolysis are regulated by catabolic and anabolic hormones. The anabolic hormone insulin initiates its action after binding to the insulin receptor, a process that starts an intracellular signaling cascade. The binding of insulin and its receptor brings closer of the two insulin receptor $\beta$-subunit, which is a tyrosine kinase, and leads to auto-phosphorylation of tyrosine residues on each other [11]. Subsequently, activated $\beta$-subunits phosphorylate Insulin Receptor Substrate (IRS) proteins, with IRS-1 being the primary IRS in skeletal muscle, which recruits and activates Phosphatidylinositol-

*Corresponding author: Guoxun Chen, Department of Nutrition, University of Tennessee at Knoxville, 229 Jessie Harris Building, 1215 West Cumberland Avenue, Knoxville, Tennessee 37996, USA, Tel: 865-974-6257; E-mail: gchen6@utk.edu

Received March 29, 2016; Accepted April 11, 2016; Published April 15, 2016

Citation: Goff M, Chen G (2016) Progresses of the Past Decade on Factors Contributing to Skeletal Muscle Glycogen Synthase Regulation. Metabolomics 6: 174. doi:10.4172/2153-0769.1000174

Copyright: (c) 2016 Goff M, et al. This is an open-access article distributed under the terms of the Creative Commons Attribution License, which permits unrestricted use, distribution, and reproduction in any medium, provided the original author and source are credited. 

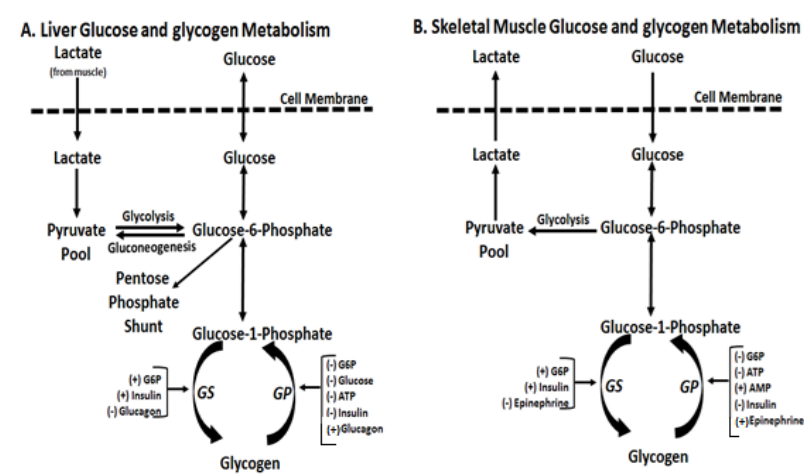

Please see the main text for explanation. The hormones or metabolites that positively or negatively affect the activities of Glycogen Synthase (GS) or Glycogen Phosphorylase (GP) are indicated as (+) and (-), respectively. Abbreviations: G6P, Glucose 6-Phosphate; ATP, Adenosine Triphosphate.

Figure 1: Differential regulations of glycogen metabolism in the liver $(A)$ and skeletal muscle (B)

3-Kinase (PI3K) [11]. Activated PI3K catalyzes the conversion of the membrane-associated Phosphatidylinositol-4,5-bisphosphate (PIP2) and ATP into phosphatidylinositol-3,4,5-triphosphate (PIP3) and ADP. The increases in PIP3 leads to the recruitment of Akt, a serine/ threonine protein kinase also referred to as Protein Kinase B (PKB), by interacting with its pleckstrin homology domain [12]. PIP3 also recruits PIP3-bound Phosphoinositide-Dependent protein Kinase-1 (PDK1) to the plasma membrane which phosphorylates Akt at Thr308 $[13,14]$. The mammalian Target of Rapamycin Complex (mTORC2) will phosphorylate Akt at Ser473 leading to its activation [15]. In muscle cells, the insulin stimulation leads to an increase in amount of Glucose Transporter 4 (GLUT4) on the cell membrane, which is translocated from intracellular storage vesicles [16]. Akt will inactivate Glycogen Synthase Kinase-3 (GSK-3) by phosphorylating specific sites on the enzyme $[17,18]$. By inhibiting GSK-3, Glycogen Synthase Phosphatase (GSP) can activate GS by dephosphorylation $[13,19]$. The insulin signaling cascade is also associated with the activation of Protein Phosphatase 1 (PP1) which will lead to the dephosphorylation and activation of GS while inactivating GP, favoring glycogen formation [20].

Adrenaline, also referred to as epinephrine, and glucagon are catabolic hormones that stimulate an intracellular signaling cascade to promote glycogenolysis. Upon their secretion, glucagon binds to G-Protein Coupled Receptors (GPCRs) located on the surface of liver cells, whereas, adrenaline will bind to GPCRs on the surface of liver and muscle cells. The binding results in a conformation change of GPCR that leads to the Gs subunit of the stimulated G protein complex to exchange Guanine Diphosphate (GDP) for Guanine Triphosphate (GTP) and its release from the heterotrimeric complex [21]. The activated Gs will activate adenylyl cyclase, which, in turn, catalyzes the conversion of ATP into cyclic Adenosine Monophosphate (cAMP). The increase in cAMP level will activate Protein Kinase A (PKA) [21]. PKA is a complex that encompasses two regulatory subunits and two catalytic subunits. Once cAMP binds to the regulatory subunits, the complex dissociates, allowing the catalytic subunits of PKA to interact with and phosphorylate specific residues on a number of proteins [22]. Phosphorylase kinase and GS are two such proteins. The phosphorylation and activation of Phosphorylase Kinase by PKA will lead to the activation of GP, which results in glycogen breakdown
[23]. PKA will also inhibit the acetylation of GP, which decreases PP1's ability to bind to, dephosphorylate, and inactivate GP [24]. The phosphorylation of GS by PKA will result in reducing its activity, thus abrogating glycogen synthesis [25].

As insulin regulates the activities of enzymes for glycogenesis and glycogenolysis, glycogen metabolism is altered in diabetes [26]. There are numerous other conditions that can arise from or be associated with irregularities in skeletal muscle glycogen regulation [27]. The key events in the synthesis of glycogen have been well characterized, and factors affecting muscle glycogen synthesis have drawn attention for the past decade. The focus of this review is to identify factors that can potentially promote or abrogate the activities of GS as demonstrated by scholarly articles published within the past 10 years.

Studies were identified by searching the PubMed electronic database from June 2015 to February 2016. The search terms included were: skeletal muscle, glycogen, glycogen synthase. Time constraints were set on the date of publication with January, 2005-February, 2016 being eligible for inclusion. Only articles published in English were reviewed. Identified abstracts were screened for duplicates. Abstracts identified were reviewed and full articles for abstracts meeting criteria were retrieved and further evaluated.

Only original research studies reporting the influence of a manipulation that either decreases or increases in GS gene expression, protein level, and/or GS activity in which statistical significance was reported, were considered for inclusion. Both in vivo and in vitro study designs were eligible for inclusion. There was no restriction on type of subjects involved in in vivo studies to be included in this review. There was no restriction on length of experimental manipulation to be included in the review.

For the included studies, general study characteristics (author, year of publication, study design, comparison groups, and testing duration), characteristics of study population (for humans-age, gender, disease state; for animals-species, strain, disease state), experimental manipulation (exercise, diet, compound treatment), and study outcomes (regulation of GS gene expression, protein levels, and/or activity) were extracted from the included studies. MG independently extracted data from each study. Discrepancies regarding data extraction in studies were resolved by discussion with GC.

All extracted studies were divided into two categories based upon the study outcomes: promotion or abrogation of GS regulation. All identified studies had to report on at least one of the following outcomes: promotion or abrogation of GS gene expression, protein level, and/or activity. Studies that reported only on upstream or downstream factors of GS, but did not specifically report significant findings on GS were excluded from this review.

\section{Factors Promoting GS Regulation}

Factors leading to the positive regulation of GS have been of much interest within the past decade in both human (Table 1) and animal (Table 2) model systems.

\section{Behavior and physical activity}

As shown in Table 1, a study investigating the effects of a 6-month weight loss and aerobic activity program in elderly insulin-resistant men found that glucose utilization in them improved [28]. This is most likely due to the reported increase in insulin-induced GS activity [28] Similar results were seen in rat skeletal muscle, in which insulin and muscle contraction have an additive effect on induction of GS activity 
Citation: Goff M, Chen G (2016) Progresses of the Past Decade on Factors Contributing to Skeletal Muscle Glycogen Synthase Regulation. Metabolomics 6: 174. doi:10.4172/2153-0769.1000174

Page 3 of 11

Table 1: Factors positively impacting GS regulation in studies using human materials.

\begin{tabular}{|c|c|c|c|c|c|}
\hline Factor/Manipulation & $\begin{array}{l}\text { Participants/Model } \\
\text { System }\end{array}$ & $\begin{array}{l}\text { Treatment/Manipulation; } \\
\text { Duration }\end{array}$ & Findings & Proposed Mechanisms & Citation \\
\hline \multirow[t]{5}{*}{$\begin{array}{l}\text { Physical Activity/Muscle } \\
\text { Contraction }\end{array}$} & $\begin{array}{l}\text { Obese subjects with or } \\
\text { without T2DM (examined } \\
\text { vastus lateralis muscle) }\end{array}$ & $\begin{array}{l}\text { On a cycle ergometer for } 60 \mathrm{~min} \\
\text { at an intensity }\left(\sim 70 \% \mathrm{VO}_{2 \max }\right) \\
\text { followed with } 1-3 \mathrm{~h} \text { of recovery } \\
\text { period }\end{array}$ & $\begin{array}{l}\uparrow \text { GS activity } \\
\downarrow \text { GS phosphorylation at } \\
\text { Ser7/10/640/644 }\end{array}$ & $\begin{array}{l}\text { Exercise increases substrate } \\
\text { affinity and decreases GSK- } 3 \beta \\
\text { activity. }\end{array}$ & 30 \\
\hline & $\begin{array}{l}\text { Lean and obese } \\
\text { subjects with normal } \\
\text { glucose tolerance, } \\
\text { obese subjects with } \\
\text { T2DM (examined vastus } \\
\text { lateralis muscle) }\end{array}$ & $\begin{array}{l}\text { On a cycle ergometer for } 40 \mathrm{~min} \\
\text { at an intensity }\left(\sim 70 \% \mathrm{VO}_{2 \max }\right)\end{array}$ & $\begin{array}{l}\downarrow \text { Glycogen content and } \\
\text { GS phosphorylation at } \\
\text { Ser7/641/645/649/653/657 }\end{array}$ & $\begin{array}{l}\text { Exercise increases GS affinity } \\
\text { for UDP-glucose and decreases } \\
\text { GS phosphorylation at } \\
\text { Ser7/641/645/649/653/657. }\end{array}$ & 31 \\
\hline & $\begin{array}{l}\text { Obese subjects with or } \\
\text { without T2DM (examined } \\
\text { vastus lateralis muscle) }\end{array}$ & $\begin{array}{l}\text { On cycle ergometer with four to } \\
\text { five sessions of } 20 \text { to } 35 \text { min per } \\
\text { week at an average intensity ( } \\
\left.65 \% V_{2 \max }\right)-10 \text { weeks }\end{array}$ & $\begin{array}{l}\uparrow \text { GS activity and GS protein } \\
\text { level }\end{array}$ & $\begin{array}{l}\text { Exercise can increase TBC1D4 } \\
\text { signaling and influence key } \\
\text { insulin-signaling protein levels. }\end{array}$ & 32 \\
\hline & $\begin{array}{l}\text { Healthy, elderly male } \\
\text { subjects (examined } \\
\text { vastus lateralis muscle) }\end{array}$ & $\begin{array}{l}\text { On cycle ergometers twice per } \\
\text { week, strength and mobility } \\
\text { training once per week and a } 5 \\
\text { km walk once a week. } 8 \text { weeks }\end{array}$ & $\begin{array}{l}\uparrow \text { Glycogen content and GS } \\
\text { protein level } \\
\downarrow \text { GS phosphorylation at } \\
\text { Ser7/10/640 }\end{array}$ & $\begin{array}{l}\text { Exercise enhances glucose } \\
\text { uptake and decreases GS } \\
\text { (Ser7/10/640) phosphorylation. }\end{array}$ & 33 \\
\hline & $\begin{array}{l}\text { Middle-aged sedentary } \\
\text { or regularly active } \\
\text { subjects (examined } \\
\text { vastus lateralis muscle) }\end{array}$ & $\begin{array}{l}\text { Male subjects who performed } \\
\text { endurance training (running } \\
\text { and cycling) must have done } \\
\text { so for years previous to study. } \\
\text { Duration: } 4 \text { to } 7 \text { days between } \\
\text { screening day and experimental } \\
\text { (biopsy) day }\end{array}$ & $\uparrow$ GS protein level & $\begin{array}{l}\text { Mechanism not described in } \\
\text { detail, however, having a high } \\
\mathrm{VO}_{2 \max } \text { may influence insulin } \\
\text { sensitivity in muscle. }\end{array}$ & 34 \\
\hline \multirow{2}{*}{$\begin{array}{c}\text { Calorie } \\
\text { Restriction+Physical } \\
\text { Activity }\end{array}$} & $\begin{array}{l}\text { Older, overweight/obese } \\
\text { insulin-resistant subjects } \\
\text { (examined vastus } \\
\text { lateralis muscle) }\end{array}$ & $\begin{array}{l}\text { Aerobic exercise training } \\
\text { (treadmill at } 50-70 \% \mathrm{VO}_{2 \max } \\
\text { for } 20 \text { to } 50 \mathrm{~min} \text { ) +weight loss } \\
\text { (restrict intake by } 500 \text { calories/ } \\
\text { day). } 6 \text { months }\end{array}$ & $\uparrow$ GS activity (vs. baseline) & $\begin{array}{l}\text { Calorie restriction+physical } \\
\text { activity may enhance whole- } \\
\text { body insulin sensitivity. }\end{array}$ & 28 \\
\hline & $\begin{array}{l}\text { Healthy, overweight, or } \\
\text { obese post-menopausal } \\
\text { women with normal } \\
\text { or impaired glucose } \\
\text { tolerance (examined } \\
\text { vastus lateralis muscle) }\end{array}$ & $\begin{array}{l}\text { Women exercised at }>85 \% \text { heart } \\
\text { rate reserve for } 45 \mathrm{~min}, 3 \times \text { per } \\
\text { week and/or were instructed to } \\
\text { reduce their caloric intake by } 500 \\
\text { kcal/day. } 6 \text { months }\end{array}$ & $\begin{array}{l}\uparrow \text { GS activity (in women with } \\
\text { impaired glucose tolerance who } \\
\text { exercised and restricted calories } \\
\text { vs. restricted calories alone) }\end{array}$ & $\begin{array}{l}\text { Calorie restriction+physical } \\
\text { activity may enhance whole- } \\
\text { body insulin sensitivity. }\end{array}$ & 35 \\
\hline GSK-3 $\alpha$ Repression & $\begin{array}{l}\text { Human skeletal muscle } \\
\text { cells isolated from } \\
\text { nondiabetic subjects } \\
\text { (biopsy samples of the } \\
\text { vastus lateralis) }\end{array}$ & $\begin{array}{l}\text { Antisense oligo against GSK-3a } \\
\text { were used for } 6 \text { h to knockdown } \\
\text { expression in differentiating } \\
\text { cells. Insulin ( } 33 \mathrm{nM} \text { ) for } 30 \text { min. }\end{array}$ & $\begin{array}{l}\uparrow \text { insulin-stimulated GS } \\
\text { fractional velocity }\end{array}$ & $\begin{array}{l}\text { GSK-3a repression may } \\
\text { enhance insulin actions while } \\
\text { overexpression can lead to } \\
\text { insulin signaling impairment. }\end{array}$ & 41 \\
\hline GSK-3 $\beta$ Repression & $\begin{array}{l}\text { Human skeletal muscle } \\
\text { cells obtained from } \\
\text { nondiabetic subjects } \\
\text { (biopsy samples of the } \\
\text { vastus lateralis) }\end{array}$ & $\begin{array}{l}\text { Transfection of cultured muscle } \\
\text { cells with siRNA against GSK- } \\
3 \beta \text { for } 4 \text { h. Insulin }(33 \mathrm{nM}) \text { for } \\
30 \text { min. }\end{array}$ & $\begin{array}{l}\uparrow \text { basal and insulin-stimulated } \\
\text { GS fractional velocity }\end{array}$ & 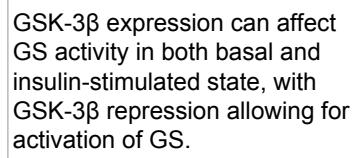 & 43 \\
\hline IL-6 & $\begin{array}{l}\text { Human skeletal muscle } \\
\text { cells obtained from } \\
\text { nondiabetic subjects } \\
\text { (biopsy samples of } \\
\text { rectus abdominus) }\end{array}$ & $\begin{array}{l}\text { IL- } 6(5,25 \text {, or } 100 \mathrm{ng} / \mathrm{ml}) \text {. } \\
\text { treatment for } 20 \mathrm{~min}, 3 \mathrm{~h} \text {, or } 8 \\
\text { days }\end{array}$ & $\begin{array}{l}\uparrow \text { Glycogen synthesis (IL-6 } \geq 5 \\
\mathrm{ng} / \mathrm{mL} \text { ) } \\
\uparrow \mathrm{GS} \text { mRNA expression (IL-6 } 25 \\
\mathrm{ng} / \mathrm{mL}, 8 \text { days) }\end{array}$ & $\begin{array}{l}\text { IL-6 increases glycogen } \\
\text { synthesis via a PI3-kinase- } \\
\text { dependent mechanism. }\end{array}$ & 47 \\
\hline Adiponectin & $\begin{array}{l}\text { Lean subjects, obese } \\
\text { subjects with or without } \\
\text { T2DM (examined vastus } \\
\text { lateralis muscle) }\end{array}$ & $\begin{array}{l}\text { Euglycemic -hyperinsulinemic } \\
\text { clamp performed for } 4 \mathrm{~h}\end{array}$ & $\begin{array}{l}\uparrow \text { insulin-stimulated GS } \\
\text { fractional velocity (positive } \\
\text { association with plasma } \\
\text { adiponectin levels) }\end{array}$ & $\begin{array}{l}\text { Plasma adiponectin may } \\
\text { improve the ability to switch } \\
\text { from lipid to glucose oxidation, } \\
\text { and enhance muscle insulin } \\
\text { sensitivity. }\end{array}$ & 48 \\
\hline Pioglitazone & $\begin{array}{l}\text { Obese women with } \\
\text { PCOS (examined vastus } \\
\text { lateralis muscle) }\end{array}$ & $\begin{array}{l}\text { Euglycemic-hyperinsulinemic } \\
\text { clamp performed for } 3 \\
\text { h. Treatment with either } \\
\text { pioglitazone }(30 \mathrm{mg}) \text { or placebo } \\
\text { once daily - } 16 \text { weeks }\end{array}$ & $\begin{array}{l}\uparrow \text { insulin -stimulated GS activity } \\
\text { and dephosphorylation of GS } \\
\text { atSer7/640/644 }\end{array}$ & $\begin{array}{l}\text { Pioglitazone enhances insulin } \\
\text { sensitivity and GS activity by } \\
\text { promoting insulin-mediated } \\
\text { dephosphorylation of GS at } \\
\text { Ser7/640/644. }\end{array}$ & 57 \\
\hline
\end{tabular}

Abbreviations: GS=Glycogen Synthase, GSK=Glycogen Synthase Kinase, IL-6=Interleukin-6, mRNA=messenger Ribonucleic Acid, PCOS=Polycystic Ovary Syndrome, T2DM=type 2 Diabetes Mellitus, TBC1D4=Tre-2/USP6, BUB2, Cdc16 domain family, member 4, UDP=Uridine Diphosphate, $\uparrow=s i g n i f i c a n t$ increases due to factor/ manipulation, $\downarrow=$ significant decreases due to factor/manipulation. 
Citation: Goff M, Chen G (2016) Progresses of the Past Decade on Factors Contributing to Skeletal Muscle Glycogen Synthase Regulation. Metabolomics 6: 174. doi:10.4172/2153-0769.1000174

Page 4 of 11

Table 2: Factors positively impacting GS regulation in animal studies.

\begin{tabular}{|c|c|c|c|c|c|}
\hline $\begin{array}{c}\text { Factorl } \\
\text { Manipulation }\end{array}$ & Participants/Model System & $\begin{array}{l}\text { Treatment/Manipulation; } \\
\text { Duration }\end{array}$ & Findings & Proposed Mechanisms & Citation \\
\hline \multirow{3}{*}{$\begin{array}{l}\text { Physical } \\
\text { Activity/Muscle } \\
\text { Contraction }\end{array}$} & $\begin{array}{l}\text { Male Wistar rats (examined } \\
\text { epitrochlearis muscle) }\end{array}$ & $\begin{array}{c}\text { Muscles were kept rested or } \\
\text { contracted electrically while } \\
\text { incubating with or without insulin } \\
(10 \mathrm{mU} / \mathrm{mL}) \text { for } 30 \mathrm{~min}\end{array}$ & $\begin{array}{c}\uparrow \text { insulin-stimulated GS activity } \\
\downarrow \text { GS phosphorylation at } \\
\text { Ser645/649/653/657 }\end{array}$ & $\begin{array}{l}\text { Muscle contraction } \\
\text { can increase AMPKa } \\
\text { phosphorylation at } \\
\text { Thr172 and decrease } \\
\text { GS phosphorylation at } \\
\text { Ser645/649/653/657. }\end{array}$ & 29 \\
\hline & $\begin{array}{c}\text { Female Sprague Dawley rats } \\
\text { (examined triceps and epitrochlearis } \\
\text { muscles) }\end{array}$ & $\begin{array}{l}\text { Two groups- rats in the untrained } \\
\text { group were housed individually } \\
\text { in plastic cages and rats in the } \\
\text { trained group were housed in } \\
\text { wheel cages. Trained either for } 1 \\
\text { week, } 4 \text { weeks, or } 7 \text { weeks. }\end{array}$ & $\begin{array}{c}\uparrow \text { Glycogen content after } 4 \text { and } 7 \\
\text { weeks (triceps) } \\
\uparrow \text { GS activity after } 4 \text { and } 7 \text { weeks } \\
\text { (triceps) }\end{array}$ & $\begin{array}{c}\text { Physical activity may } \\
\text { enhance insulin sensitivity } \\
\text { and PP1 activity. }\end{array}$ & 36 \\
\hline & $\begin{array}{l}\text { Female white New Zealand rabbits } \\
\text { (examined tibialis anterior muscle) }\end{array}$ & $\begin{array}{c}\text { Electrostimulations to mimic } \\
\text { contraction were applied for } 1 \mathrm{~h} \\
\text { or } 24 \mathrm{~h} \text {. After stimulation, animals } \\
\text { were allowed to recover for } 0,1 \text {, } \\
6,12 \text {, or } 24 \mathrm{~h} \text {. }\end{array}$ & $\begin{array}{c}\uparrow \text { Glycogen content during a } 6 \\
\mathrm{~h} \text { recovery phase after a } 24 \mathrm{~h} \\
\text { stimulation } \\
\uparrow \mathrm{GS} \text { activity } \\
\downarrow \text { GP activity and GS (Ser640) } \\
\text { phosphorylation }\end{array}$ & $\begin{array}{c}\text { Prolonged muscle } \\
\text { contraction can increase GS } \\
\text { activity by decreasing GS } \\
\text { phosphorylation at Ser640 } \\
\text { while decreasing GP activity. }\end{array}$ & 37. \\
\hline $\begin{array}{c}\text { GLUT4 } \\
\text { Repression }\end{array}$ & $\begin{array}{c}\text { Wild-type and muscle-specific } \\
\text { GLUT4-knockout mice } \\
\text { Parent strains - 129SV and } \\
\text { C57BI/6J mice (examined soleus, } \\
\text { gastrocnemius, and tibialis anterior } \\
\text { muscles) }\end{array}$ & $\begin{array}{l}\text { Transgenic mice with muscle- } \\
\text { specific GLUT4 knockout. } \\
\text { Electrical stimulation to mimic } \\
\text { contraction. Mice were studied at } \\
\quad 4 \text { to } 12 \text { months of age. }\end{array}$ & $\begin{array}{c}\uparrow \text { Glycogen content } \\
\uparrow \mathrm{GS} \text { activity (tibialis anterior } \\
\text { and gastrocnemius) } \\
\downarrow \text { GS phosphorylation at Ser641 } \\
\text { (gastrocnemius) } \\
\downarrow \text { GP activity (tibialis anterior } \\
\text { and gastrocnemius) }\end{array}$ & $\begin{array}{l}\text { Decreased muscle glucose } \\
\text { transport was associated } \\
\text { with decreasing GS } \\
\text { phosphorylation at Ser641 } \\
\text { and GP activity. }\end{array}$ & 38 \\
\hline \multirow[t]{2}{*}{$\begin{array}{c}\text { AMPK } \\
\text { overexpression }\end{array}$} & $\begin{array}{c}\text { Wild-type and transgenic mice with } \\
\text { AMPKY3 or AMPKY3 R225Q mutant } \\
\text { overexpressions } \\
\text { Parent strain - FVB mice (examined } \\
\text { EDL, soleus, gastrocnemius, and } \\
\text { tibialis anterior muscles) }\end{array}$ & $\begin{array}{l}\text { Mice were compared at } 8 \text { to } 10 \\
\text { weeks of age. }\end{array}$ & $\begin{array}{c}\uparrow \text { Glycogen content (both } \\
\text { transgenic models; EDL, } \\
\text { gastrocnemius, } \\
\text { and tibialis anterior) } \\
\uparrow \text { GS activity (both transgenic } \\
\text { models in presence of G6P; } \\
\text { gastrocnemius) } \\
\downarrow \text { GP activity (wild-type AMPKү3 } \\
\text { mice; gastrocnemius) }\end{array}$ & $\begin{array}{l}\text { Mechanism not described in } \\
\text { detail, however, postulated } \\
\text { that AMPKY could alter } \\
\text { the function of the AMPK } \beta \\
\text { subunit's glycogen-binding } \\
\text { domain in stimulating the } \\
\text { activity of the glycogen } \\
\text { debranching enzyme. }\end{array}$ & 39 \\
\hline & $\begin{array}{c}\text { Wild-type and AMPK overexpressing } \\
\text { mice } \\
\text { (examined EDL, soleus, quadriceps, } \\
\text { gastrocnemius, and tibialis anterior } \\
\text { muscles) }\end{array}$ & $\begin{array}{c}\text { Mice were compared at } 9 \text { to } 12 \\
\text { weeks of age. }\end{array}$ & $\begin{array}{c}\uparrow \text { Glycogen content (quadriceps, } \\
\text { gastrocnemius, } \\
\text { and tibialis anterior) } \\
\uparrow \text { GS activity (gastrocnemius) }\end{array}$ & $\begin{array}{c}\text { With AMPKy overexpression, } \\
\text { there was reduction of } \\
\text { G6P content which may } \\
\text { result from increased G6P } \\
\text { utilization and glycogen } \\
\text { synthesis. }\end{array}$ & 40 \\
\hline SKIP repression & Mouse $\mathrm{C} 2 \mathrm{C} 12$ muscle cells & $\begin{array}{c}\text { Transfection of cultured C2C12 } \\
\text { cells with siRNA against SKIP } \\
\text { gene for } 48 \mathrm{~h} \text {. Insulin (10 and } 100 \\
\mathrm{nM} \text { ) for } 30 \mathrm{~min} .\end{array}$ & $\begin{array}{c}\uparrow \text { insulin-stimulated glycogen } \\
\text { synthesis and dephosphorylation } \\
\text { of GS at Ser641 }\end{array}$ & $\begin{array}{l}\text { SKIP negatively regulates } \\
\text { the insulin-signaling } \\
\text { pathway. Repression of SKIP } \\
\text { allows for insulin-stimulated } \\
\text { glycogen synthesis. }\end{array}$ & 49 \\
\hline Oxidant Stress & $\begin{array}{c}\text { Female lean Zucker rats at 9-10 } \\
\text { weeks of age (examined soleus } \\
\text { muscle) }\end{array}$ & $\begin{array}{l}\text { Isolated muscle incubated for } 2 \mathrm{~h} \\
\text { in the absence or presence of } 100 \\
\mathrm{mU} / \mathrm{mL} \text { glucose oxidase without } \\
\text { or with } 5 \mathrm{mU} / \mathrm{ml} \text { insulin }\end{array}$ & $\begin{array}{c}\uparrow \text { basal glycogen synthesis and } \\
\text { GS activity }\end{array}$ & $\begin{array}{l}\text { Oxidant stress increased } \\
\text { phosphorylation of insulin } \\
\text { receptor, Akt at Ser473, and } \\
\text { GSK-3 } \beta \text { at Ser9. }\end{array}$ & 50 \\
\hline $\begin{array}{l}\text { Whey Protein } \\
\text { Hydrolysates }\end{array}$ & $\begin{array}{l}\text { Male ddY mice (examined } \\
\text { gastrocnemius muscle) }\end{array}$ & $\begin{array}{c}\text { Mice fed } 1 \text { of } 3 \text { test diets for } 5 \\
\text { weeks using AIN- } 93 \text { protocol: } \\
\text { control diet, control+39.550 } \\
\text { g/kg of whey amino acids, } \\
\text { control }+50.00 \mathrm{~g} / \mathrm{kg} \text { of whey } \\
\text { protein hydrolysates. }\end{array}$ & $\begin{array}{c}\uparrow \text { Glycogen content (whey } \\
\text { protein hydrolysates>whey } \\
\text { amino acids>control) } \\
\uparrow \text { GS mRNA expression and } \\
\text { GS protein level (whey protein } \\
\text { hydrolysates) } \\
\downarrow \text { GS phosphorylation at Ser641 } \\
\text { (whey protein hydrolysates) }\end{array}$ & $\begin{array}{l}\text { Consumption of Whey } \\
\text { protein decreases GS } \\
\text { phosphorylation at Ser641 } \\
\text { and could decrease } \\
\text { 6-phosphofructokinase } \\
\text { (regulatory glycolytic } \\
\text { enzyme) activity to increase } \\
\text { GS and glycogen content. }\end{array}$ & 52 \\
\hline Linoleate & Rat L6 skeletal muscle cells & $\begin{array}{l}\text { Differentiating myotubes pre- } \\
\text { treated for } 16 \mathrm{~h} \text { with } 1 \mathrm{mM} \\
\text { linoleate in the absence or } \\
\text { presence of insulin }(100 \mathrm{nM}) \text { for } \\
1 \mathrm{~h} \text {. }\end{array}$ & $\begin{array}{c}\uparrow \text { basal and insulin -stimulated } \\
\text { GS protein level (insoluble } \\
\text { fraction) }\end{array}$ & $\begin{array}{l}\text { GS was sequestered } \\
\text { from activation by insulin } \\
\text { treatment due to lipid } \\
\text { treatment. }\end{array}$ & 53 \\
\hline OA & $\begin{array}{l}\text { Control and streptozotocin-induced } \\
\text { diabetic male Sprague-Dawley rats } \\
\text { (examined hindquarter muscle) }\end{array}$ & $\begin{array}{l}\text { Rats were treated with insulin } \\
(4 \mathrm{IU} / \mathrm{kg}), \mathrm{OA}(80 \mathrm{mg} / \mathrm{kg}), \text { or the } \\
\text { combination of OA+insulin in } \\
\text { acute ( } 60 \mathrm{~min}) \text { and sub-chronic } \\
\text { (14 days) studies. }\end{array}$ & $\begin{array}{c}\uparrow \mathrm{GS} \text { activity after insulin+OA in } \\
\text { diabetic group }\end{array}$ & $\begin{array}{c}\text { OA enhances insulin } \\
\text { signaling pathway including } \\
\text { phosphorylation of Akt at } \\
\text { Ser473 }\end{array}$ & 56 \\
\hline
\end{tabular}




\begin{tabular}{|c|c|c|c|c|c|}
\hline TFE3 & $\begin{array}{c}\text { Control and transgenic mice } \\
\text { expressing TFE3 } \\
\text { Parent strain-C57BI/6J mice } \\
\text { (examined gastrocnemius } \\
\text { quadriceps, tibialis anterior muscle) }\end{array}$ & $\begin{array}{c}\text { Transgenic mice developed to } \\
\text { muscle-specifically express TFE3. } \\
\text { Mice used at } 2 \text { to } 3 \text { months of } \\
\text { age. }\end{array}$ & $\begin{array}{c}\uparrow \text { Glycogen content in } \\
\text { gastrocnemius and quadriceps } \\
\uparrow \mathrm{GS} \text { mRNA expression in } \\
\text { gastrocnemius }\end{array}$ & $\begin{array}{l}\text { TFE3 may be involved in } \\
\text { increasing glucose uptake } \\
\text { and substrate availability } \\
\text { for GS. }\end{array}$ & 51 \\
\hline
\end{tabular}

Abbreviations: AMPK=5'-AMP-Activated Protein Kinase, EDL=Extensor Digitorum Longus, GP=Glycogen Phosphorylase, GS=Glycogen Synthase, G6 =Glucose-6Phosphate, mRNA=messenger Ribonucleic Acid, OA=oleanolic acid, PP1=Protein Phosphatase 1, SKIP=Skeletal muscle and Kidney-enriched Inositol Phosphatase, TFE3=Transcription Factor E3, $\uparrow=$ significant increases due to factor/manipulation, $\downarrow=$ significant decreases due to factor/manipulation.

that correlated to decreases in GS phosphorylation [29]. It has been shown that exercise-induced activation of muscle GS in obesity and Type 2 Diabetes Mellitus (T2DM) is associated with dephosphorylation of GS at sites Ser7, Ser10, Ser640, and Ser644 [30]. These results were further confirmed in another study using obese individuals displaying normal glucose tolerance and T2DM subjects with their GS fractional activity (GS activity in the presence of G6P divided by total GS activity) being increased and GS phosphorylation decreased post-exercise [31]. In obese individuals with T2DM and obese non-diabetic individuals, a 10 -week endurance exercise regime increased protein content of Akt, Cdc16 domain family, member 4 (TBC1D4), 5'-AMP-Activated Protein Kinase (AMPK), GS, and GLUT4 in their vastus lateralis muscle [32]. Furthermore, in 12 elderly male subjects who completed 8 week exercise training, GS and glycogen content were increased in their vastus lateralis muscle [33]. The dephosphorylation of GS at Ser7/10/640 was enhanced after the exercise intervention [33]. Another group who investigated the effects of endurance training on glucose metabolism in skeletal muscle found that in middle-aged males who regularly perform endurance physical activity had significantly higher GS protein levels than that of healthy sedentary controls [34]. Post-menopausal obese women with impaired glucose tolerance, who performed either a 6-month period of caloric restriction (subtract 500 calories daily from their typical diet) or caloric restriction+aerobic exercise $(3 \mathrm{x} /$ week for $45 \mathrm{~min}$ ), those who performed both exercise and caloric restriction had greater GS activity than those with only the caloric restriction [35]. Collectively, these results indicate that repetitive muscular contraction may be beneficial in obese, insulin-resistant, and elderly individuals in regards to the regulation of glucose.

To understand the mechanisms for exercise-induced increases in muscle glycogen, the effects of exercise training on glycogen regulatory proteins in female Sprague Dawley rats performing voluntary wheel running for 1, 4 or 7 weeks were investigated [36]. It was found that rat muscle glycogen and GS did not change after 1 week of training, but increased significantly after 4 and 7 weeks. Consistent with the GS activity, one of its primary activators, PP1 activity was also significantly increased after 4 and 7 weeks of training [36]. Exercise is also associated with a phenomenon known as glycogen overcompensation which prepares the body for bouts of strenuous exercise. When the tibialis anterior of rabbits were stimulated for $24 \mathrm{~h}$ to mimic exercise, glycogen level increased and remained at least $50 \%$ greater than the basal level for $6 \mathrm{~h}$ after stimulation [37]. The increase in glycogen correlated with a decrease in GP activity and an increase in the GS activity due to its dephosphorylation [37].

\section{Components in signal transduction pathways}

Mice with the muscle-specific knockout of GLUT4 have been shown to have increased GS activity and decreased GP activity following an overnight fasting (basal state), whereas contraction-induced glycogen breakdown remains normal [38]. The GLUT4 knockout mice display reductions in glucose transport that are associated with reductions in the IRS-1/Akt-PI3K signaling pathway. However, the increases in GS during basal state in these mice are correlated to increases in the activity of PP1 and protein levels of hexokinase II, muscle-specific regulatory subunit $\left(\mathrm{R}_{\mathrm{GL}}\right)$, and Protein Targeting to Glycogen (PTG) compared to wild-type mice [38]. Therefore, the catalytic activity of PP1 of mice in fasting state seems to dominate over the actions of GSK-3 effects, allowing for the increase in muscle glycogen content.

Of the AMPK heterotrimeric complex, the $\gamma 3$ subunit is specifically expressed in skeletal muscle [39]. Transgenic mice with skeletal muscle-specific overexpressing the $\gamma 3$ AMPK subunit had increased glycogen content and GS activity, and decreased GP activity [39]. Another group who developed a murine model of chronic skeletal muscle AMPK activation, found a selective increase in skeletal muscle glycogen content [40]. This increase in glycogen content was attributed to the catalytic $\alpha$-subunit of AMPK [40].

A study aimed to elucidate the role of the GSK-3a in insulin resistance of human skeletal muscle cells from non-diabetic subjects found that the reduction of GSK-3 $\alpha$ expression resulted in an increase of the insulin-induced glucose uptake and GS fractional velocity. However, the same effects were not witnessed in the basal state [41].

In a study investigating insulin-stimulated GS activity in human skeletal muscle, the increase in GS activity was positively associated with phosphorylation of Akt at Thr308 site and total Akt expression while both proteins were shown to be negatively associated with $\mathrm{NH} 2$ terminal GS phosphorylation [42]. The authors reported no association with the activation of GS with the phosphorylation of Akt at Ser473 site or with IRS-1-PI3K signaling [42]. In cultured human skeletal muscle cells, it was shown that the knockdown of GSK-3 $\beta$ using siRNA had no effect on total GS activity. However, GS phosphorylation was decreased due to the absence of GSK-3 $\beta$ leading to increase in GS fractional velocity at the basal as well as insulin-stimulated states [43].

Pompe disease, also known as Glycogen Storage Disease (GSD) type II, is caused by deficiency of lysosomal acid $\alpha$-glucosidase (GAA). Muscle lysates collected from $\mathrm{GAA}^{-1}$ mouse strains had elevated GS, glycogenin, hexokinase, and G6P, and decreased GP activity in the absence of AMP [44]. It has been shown that recombinant human GAA (rhGAA) can improve the clinical outcomes of Pompe disease with variable results [45]. The co-administration of rapamycin (mTORC1 inhibitor) with rhGAA in a GAA knockout mouse model led to reduction of glycogen content in muscle more than rhGAA or rapamycin alone, suggesting inhibition of mTORC1 signaling can provide outcome benefits in certain GSDs [45].

\section{Cytokines}

Interleukin-6 (IL-6) is a cytokine that has both anti- and proinflammatory actions depending on the tissue affected [46]. A group who used primary human skeletal muscle cells to investigate the role of IL-6 in muscle cell differentiation and glucose metabolism found that chronic exposure of the cells to IL-6 $(25 \mathrm{ng} / \mathrm{mL})$ resulted in an increase in glucose uptake and incorporation into glycogen which was associated with increased gene expression levels of GLUT4 and GS 
[47]. The effect that IL-6 had on glucose metabolism was attributed to the regulation of the PI3-kinase pathway since the PI3-kinase inhibitor LY294002 suppressed the aforementioned IL-6 effects [47].

Another cytokine that has an impact on glucose metabolism and insulin resistance is adiponectin. Plasma adiponectin has been found to be significantly reduced in T2DM subjects compared to obese and lean subjects [48]. In these same subjects, plasma adiponectin level was positively associated with insulin-stimulated glucose disposal and oxidation, and stimulation of skeletal muscle GS activity, but negatively associated with lipid oxidation after adjustment for body fat [48].

A protein known as Skeletal muscle and Kidney-enriched Inositol Phosphatase (SKIP) is a phosphatase that converts $\mathrm{PI}(3,4,5) \mathrm{P} 3$ to $\mathrm{PI}(3,4)$ $\mathrm{P} 2$, which negatively regulates the insulin-induced glycogen synthesis in skeletal muscle [49]. It has been shown that overexpression of the wild-type SKIP gene in differentiating mouse $\mathrm{C} 2 \mathrm{C} 12$ skeletal muscle cells leads to decreases in the insulin-stimulated glycogen synthesis. However, using siRNA that targeted the SKIP gene allowed insulin to induce the phosphorylation of Akt and GSK-3 $\beta$ with the subsequent dephosphorylation and activation of GS [49]. Obviously, the SKIP gene could be of much research interest in discovering possible therapeutic interventions for GSDs.

The molecular actions of oxidant stress on insulin signaling and glucose transport have been studied in isolated soleus muscle of lean Zucker rats. It was found that oxidant stress $(100 \mathrm{mU} / \mathrm{mL}$ glucose oxidase) alone led to significant increases in basal glucose transport, glycogen synthesis, and GS activity concomitant with increases in the phosphorylation of insulin receptor, Akt at Ser473, and GSK-3 $\beta$ at Ser9 [50]. However, oxidant stress had negative effects on the insulinstimulated glucose transport and glycogen synthesis [50].

The effects of Transcription Factor E3 (TFE3) were examined in transgenic mice who selectively expressed TFE3 in their skeletal muscle to better understand its effects on skeletal muscle glucose regulation [51]. The glycogen content in skeletal muscle of TFE3 transgenic mice was more than twofold higher than that of wild-type mice, and this effect was associated with an upregulation of the mRNA expression levels of GLUT4, hexokinase II, and GS. Interestingly, these transgenic mice also displayed enhanced insulin sensitivity and exercise endurance capacity [51].

\section{Nutritional factors}

When mice were fed an experimental diet containing Whey Protein Hydrolysates (WPH), a mixture of Whey Amino Acids (WAAs), or casein for 5 weeks, the gastrocnemius muscle glycogen level was significantly higher in the WPH group than in the WAA or casein group [52]. Furthermore, the WPH group exhibited significantly higher total GS protein level and lower phosphorylated GS level than the WAA or control group had [52].

A study using rat L6 skeletal muscle cells found that linoleate $(1 \mathrm{mM})$ can increase GS protein in insoluble, but not cytosolic or membrane fractions during both the basal and insulin-stimulated state [53]. Studies have shown that the plant derived Oleanolic Acid (OA) can have antidiabetic effects [54,55]. One study investigated the effects of $\mathrm{OA}$ in skeletal muscle of streptozotocin-induced diabetic male Sprague Dawley rats [56]. Following treatment with insulin (4 $\mathrm{IU} / \mathrm{kg})$, OA ( $80 \mathrm{mg} / \mathrm{kg})$, or the combination of OA+insulin for 14 days, GS activity was significantly increased in diabetic rats receiving both $\mathrm{OA}$ and insulin compared with non-diabetic and diabetic controls [56].

\section{Pharmaceutical reagents}

Women with Polycystic Ovary Syndrome (PCOS) typically display reduced insulin-mediated glycogen synthesis in skeletal muscle [57]. After a 16- week treatment with pioglitazone ( $30 \mathrm{mg} /$ day), patients with PCOS displayed improved insulin-stimulated glucose metabolism and GS activity. This action was attributed to restoration of insulin's ability to dephosphorylate GS [57].

\section{Factors Abrogating GS Regulation}

Studies performed in the past decade have elucidated a number of factors that regulate GS negatively in both human (Table 3) and animal (Table 4) model systems.

\section{Genetic defects}

It has been reported that a frameshift mutation in PPP1R3A, the gene encoding RGL resulted in decreased skeletal muscle GS activity with concomitant increases in GP activity in mice [58]. Humans expressing this variant have low basal and postprandial muscle glycogen content [58]. Pompe disease is a rare condition characterized by abnormal glycogen regulation leading to myopathy [59,60]. In an effort to find ways to decrease skeletal muscle glycogen accumulation seen with Pompe disease, a group of researchers discovered that a Phosphorodiamidate Morpholino Oligonucleotide (PMO) designed to invoke exon skipping in the transcript for muscle specific GS led to a dose-dependent decrease in GS transcripts in the quadriceps of mice [61]. This resulted in the reductions of skeletal muscle GS level and activity in the mice [61].

\section{Components in signal transduction pathways}

Regulation the activity of AMPK pathway: In isolated rat muscle treated for $40 \mathrm{~min}$ with the AMPK activator 5-aminoimidazole-4carboxamide-1- $\beta$-D-ribonucleoside (AICAR, $2 \mathrm{mM}$ ) and insulin (1 $\mu \mathrm{M})$, insulin-stimulated GS activity was decreased whereas lactate release was markedly increased [62]. Similar results were seen in another study in which rat soleus muscle was treated for $30 \mathrm{~min}$ with AICAR $(2 \mathrm{mM})$ before insulin $(100 \mathrm{nM})$ was added to the samples for 45, 60 and $75 \mathrm{~min}$ [63]. AICAR treatment significantly suppressed insulin-stimulated glycogen synthesis which correlated with the increase in the phosphorylation of GS [63]. The AICAR treatment in this study also led to a significant increase in lactate production in rat soleus muscles [63].

Another study investigated the mechanism by which AMPK activation regulates muscle glycogen levels used AICAR, insulin, and adrenaline treatments on the Extensor Digitorum Longus (EDL) muscle of C57BL/6 mice [64]. After the treatment for $40 \mathrm{~min}$, AICAR $(2 \mathrm{mM})$ resulted in a modest but significant decrease in GS activity while no change in GS or GP phosphorylation was detected. However, treatment with adrenaline $(10 \mu \mathrm{M})$ led to a strong increase in phosphorylation of GS at Ser8 and Ser11, and in phosphorylation of GP at Ser15 which correlated with a decrease in GS activity [64]. This same study measured the effect of AICAR on GS activity in EDL muscle isolated from transgenic mice with mutant AMPKa2 (kinase dead, K45R mutation) or wild-type mice. In unstimulated muscle, the GS activity in AMPKa2 mutant mice was significantly higher than that in wild-type littermates. This was correlated with a decrease in phosphorylation of GS at sites Ser8 and Ser641. Furthermore, AICAR treatment failed to reduce GS activity in AMPKa2 mutant mice whereas wild-type mice had a significant decrease [64]. It has also been shown in primary human muscle cell cultures that a $5 \mathrm{~h}$ insulin treatment $(300$ 
Citation: Goff M, Chen G (2016) Progresses of the Past Decade on Factors Contributing to Skeletal Muscle Glycogen Synthase Regulation. Metabolomics 6: 174. doi:10.4172/2153-0769.1000174

Page 7 of 11

Table 3: Factors negatively impacting GS regulation in studies using human materials.

\begin{tabular}{|c|c|c|c|c|c|}
\hline Factor/Manipulation & $\begin{array}{c}\text { Participants/Model } \\
\text { System }\end{array}$ & Treatment/Manipulation; Duration & Findings & Proposed Mechanisms & Citation \\
\hline $\begin{array}{l}\text { Pro-longed insulin } \\
\text { treatment }\end{array}$ & $\begin{array}{l}\text { Human skeletal muscle } \\
\text { cells }\end{array}$ & Insulin $(300 \mathrm{nM})-5 \mathrm{~h}$ & $\begin{array}{c}\uparrow \text { Glycogen content } \\
\downarrow \text { GS activity and glycogen } \\
\text { synthesis rate }\end{array}$ & $\begin{array}{l}\text { Pro-longed insulin } \\
\text { treatment could result } \\
\text { in a negative feedback } \\
\text { mechanism on insulin } \\
\text { signaling pathway }\end{array}$ & 65 \\
\hline Adrenaline & $\begin{array}{l}\text { Male and female healthy } \\
\text { subjects (examined } \\
\text { tibialis anterior muscle) }\end{array}$ & $\begin{array}{c}\text { Adrenaline }(0.05 \mu \mathrm{g} / \mathrm{kg} / \mathrm{min}) \text { or saline } \\
\text { infusion for } 240 \mathrm{~min} \text {. Euglycaemic- } \\
\text { hyperinsulinemic clamp for } 120-240 \\
\text { min }\end{array}$ & $\begin{array}{c}\downarrow \text { insulin-stimulated Glycogen } \\
\text { synthesis, GS activity, and } \\
\text { dephosphorylation of GS } \\
\text { at Ser641 }\end{array}$ & $\begin{array}{c}\text { Adrenaline blocks } \\
\text { insulin-mediated GS } \\
\text { activation most likely } \\
\text { due to preventing } \\
\text { dephosphorylation of GS } \\
\text { at Ser641. }\end{array}$ & 66 \\
\hline \multirow[b]{2}{*}{ T2DM } & $\begin{array}{l}\text { Obese male subjects } \\
\text { with or without T2DM } \\
\text { (examined vastus } \\
\text { lateralis muscle) }\end{array}$ & $\begin{array}{l}\text { Exercise on a cycle ergometer for } 60 \\
\text { min at an intensity }\left(\sim 70 \% \mathrm{VO}_{2 \mathrm{max}}\right) \\
\text { followed with } 1-3 \mathrm{~h} \text { of recovery period }\end{array}$ & $\begin{array}{c}\downarrow \text { GS activity } \\
\uparrow \text { GS P-Ser7/10 during recovery } \\
\text { period (diabetic vs. obese) }\end{array}$ & $\begin{array}{c}\text { Muscle GS } \\
\text { phosphorylation regulation } \\
\text { in T2DM is impaired in } \\
\text { response to recovery from } \\
\text { exercise. }\end{array}$ & 30 \\
\hline & $\begin{array}{l}\text { Obese subjects with or } \\
\text { without T2DM, and lean } \\
\text { non-diabetic subjects } \\
\text { (examined vastus } \\
\text { lateralis muscle) }\end{array}$ & $\begin{array}{c}\text { Following overnight fast, lean } \\
\text { and obese controls underwent } \\
\text { a euglycemic-hyperinsulinemic } \\
\text { clamp ( } 4 \mathrm{~h} \text { ) with tracer glucose and } \\
\text { combined with indirect calorimetry; } \\
\text { diabetic patients were clamped } \\
\text { twice with either a euglycemic or } \\
\text { an isoglycaemic-hyperinsulinaemic } \\
\text { clamp (fixing glucose at the fasting } \\
\text { glucose level) separated by } 4-6 \\
\text { weeks }\end{array}$ & $\begin{array}{c}\downarrow \text { insulin-stimulated GS activity } \\
\text { during euglycemia } \\
\downarrow \text { insulin-stimulated } \\
\text { dephosphorylation of GS } \\
\text { at Ser7/10 during euglycemia and } \\
\text { hyperglycemia }\end{array}$ & $\begin{array}{l}\text { T2DM impairs insulin- } \\
\text { stimulated glycogen } \\
\text { synthesis involving } \\
\text { Akt phosphorylation at } \\
\text { Ser473 and Thr308, and } \\
\text { dephosphorylation of GS } \\
\text { at Ser7/10. }\end{array}$ & 69 \\
\hline PCOS & $\begin{array}{l}\text { Obese women with } \\
\text { or without PCOS } \\
\text { (examined vastus } \\
\text { lateralis muscle) }\end{array}$ & $\begin{array}{l}\text { Euglycemic-hyperinsulinemic clamp } \\
\text { performed for } 3 \mathrm{~h} \text {. }\end{array}$ & $\begin{array}{l}\downarrow \text { insulin-stimulated GS activity } \\
\text { and dephosphorylation of GS at } \\
\text { Ser7/10 (PCOS vs. control) }\end{array}$ & $\begin{array}{c}\text { PCOS decreased } \\
\text { the insulin-mediated } \\
\text { dephosphorylation of GS } \\
\text { at Ser7/10. }\end{array}$ & 57 \\
\hline Physical Inactivity & $\begin{array}{l}\text { Healthy male subjects } \\
\text { (examined vastus } \\
\text { lateralis muscle) }\end{array}$ & $\begin{array}{l}\text { Bed rest (all transport of subjects took } \\
\text { place in wheelchairs) - } 7 \text { days }\end{array}$ & $\begin{array}{c}\downarrow \text { GS activity } \\
\uparrow \text { GS phosphorylation at Ser7/10 }\end{array}$ & $\begin{array}{l}\text { Physical inactivity/bed } \\
\text { rest impairs muscle } \\
\text { insulin signaling and } \\
\text { dephosphorylation of GS } \\
\text { at Ser7/10 }\end{array}$ & 71 \\
\hline $\begin{array}{c}\text { High } \\
\text { glucose+angiotensin }\end{array}$ & $\begin{array}{l}\text { Human skeletal muscle } \\
\text { cells }\end{array}$ & $\begin{array}{l}\text { Muscle cells were incubated with or } \\
\text { without } 25 \text { mM glucose for } 24 \mathrm{~h} \text {. } \\
\text { Angiotensin treatment }(1 \mu \mathrm{M})-20 \mathrm{~min}\end{array}$ & $\begin{array}{c}\downarrow \text { GS activity } \\
\uparrow \mathrm{GS} \text { phosphorylation at } \\
\text { Ser640/641 }\end{array}$ & $\begin{array}{l}\text { Angiotensin reduced } \\
\text { ERK } 1 / 2 \text { phosphorylation } \\
\text { at Thr202/Tyr204 } \\
\text { and impaired } \\
\text { dephosphorylation of GS } \\
\text { at Ser640/641. }\end{array}$ & 72 \\
\hline
\end{tabular}

Abbreviations: BMI=Body Mass Index, ERK=Extracellular Regulated signal Kinase, GS=Glycogen Synthase, GSK=Glycogen Synthase Kinase, T2DM=type 2 Diabetes Mellitus, $\uparrow=$ significant increases due to factor/manipulation, $\downarrow=$ significant decreases due to factor/manipulation.

Table 4: Factors negatively impacting GS regulation in animal studies.

\begin{tabular}{|c|c|c|c|c|c|}
\hline Factor/Manipulation & Participants/Model System & $\begin{array}{c}\text { Treatment/Manipulation; } \\
\text { Duration }\end{array}$ & Findings & Proposed Mechanisms & Citation \\
\hline PPP1R3A Mutation & $\begin{array}{c}\text { Wild-type and mutant } \\
\text { (premature stop mutation in } \\
\text { PPP1R3A) mice Parent strain } \\
\text { - Chimeric mice cross-bed with } \\
\text { C57BL/6J mice (examined } \\
\text { muscle not specified) }\end{array}$ & $\begin{array}{l}\text { Tissues collected during } \\
\text { ad libitum. Age used not } \\
\text { described. }\end{array}$ & $\begin{array}{c}\downarrow \text { Glycogen content and } \\
\text { GS activity } \\
\uparrow \text { GP activity }\end{array}$ & $\begin{array}{c}\text { The reduction in GS activity was } \\
\text { most likely due to the inability of PP1 } \\
\text { to colocalize with GS and to bind to } \\
\text { glycogen. }\end{array}$ & 58 \\
\hline GS-PMO & $\begin{array}{c}\text { C57BL/6+GAA-/- mice } \\
\text { (examined quadriceps muscle) }\end{array}$ & $\begin{array}{c}\text { GS-PMO administered at } 15 \\
\text { or } 30 \mathrm{mg} / \mathrm{kg} \text { bodyweight by } \\
\text { tail vein injection once every } 2 \\
\text { weeks for a total of } 12 \text { weeks, } \\
\text { muscle isolated } 2 \text { weeks after } \\
\text { stopping treatment }\end{array}$ & $\begin{array}{c}\downarrow \text { Glycogen content, } \\
\text { GS activity, GS mRNA } \\
\text { expression, and GS } \\
\text { protein level }\end{array}$ & $\begin{array}{l}\text { GS-PMO forces exon skipping in the } \\
\text { processing of Gys } 1 \text { mRNA, leading to } \\
\text { a premature termination codon. }\end{array}$ & 61 \\
\hline \multirow[b]{2}{*}{ AICAR } & $\begin{array}{c}\text { Male Sprague-Dawley rats } \\
\text { (examined epitrochlearis } \\
\text { muscles) }\end{array}$ & $\begin{array}{c}\text { AICAR (2 mM) and insulin (1 } \\
\mu \mathrm{M})-40 \mathrm{~min}\end{array}$ & $\begin{array}{l}\downarrow \text { basal and insulin- } \\
\text { stimulated GS activity }\end{array}$ & $\begin{array}{l}\text { AICAR treatment favors an increase } \\
\text { in glycolytic flux instead of glycogen } \\
\text { synthesis. }\end{array}$ & 62 \\
\hline & $\begin{array}{l}\text { Male Albino-Wistar rats } \\
\text { (examined soleus and } \\
\text { epitrochlearis muscles) }\end{array}$ & $\begin{array}{l}\text { AICAR }(2 \mathrm{mM}) \text { and insulin } \\
(100 \mathrm{nM})-45,60 \text {, and } 75 \mathrm{~min} \\
\text { (preincubated with AICAR } 30 \\
\text { min before insulin added) }\end{array}$ & $\begin{array}{c}\downarrow \text { insulin-stimulated } \\
\text { glycogen synthesis and } \\
\text { glycogen content (soleus } \\
\text { muscle) } \\
\uparrow \text { GS phosphorylation at } \\
\text { Ser641 (45 min, soleus } \\
\text { muscle) }\end{array}$ & $\begin{array}{l}\text { AICAR treatment led to a time- } \\
\text { dependent reduction in Akt } \\
\text { phosphorylation at Thr308 and } \\
\text { activation of GSK-3 } \alpha / \beta \text {. }\end{array}$ & 63 \\
\hline
\end{tabular}




\begin{tabular}{|c|c|c|c|c|c|}
\hline \multirow{3}{*}{ Adrenaline } & $\begin{array}{l}\text { C57BL/6 J mice (examined } \\
\text { EDL muscle) }\end{array}$ & Adrenaline $(10 \mu \mathrm{M})-40 \mathrm{~min}$ & $\begin{array}{c}\downarrow \text { GS activity } \\
\uparrow \text { GS phosphorylation at } \\
\text { Ser8/11, GP activity, and } \\
\text { GP phosphorylation at } \\
\text { Ser15 }\end{array}$ & $\begin{array}{c}\text { Adrenaline impairs dephosphorylation } \\
\text { of GS at Ser8/11 while promoting GP } \\
\text { phosphorylation at Ser } 15 .\end{array}$ & 64 \\
\hline & $\begin{array}{l}\text { Male Wistar rats (examined } \\
\text { soleus muscle) }\end{array}$ & Adrenaline $(10 \mu \mathrm{M})$ - $30 \mathrm{~min}$ & $\begin{array}{c}\uparrow \mathrm{GS} \\
\text { (Ser645/649/653/657) } \\
\text { phosphorylation }\end{array}$ & $\begin{array}{c}\text { Adrenaline impairs dephosphorylation } \\
\text { of GS atSer645/649/653/657 most } \\
\text { likely through PKA signaling pathway, } \\
\text { which may also lead to decreases in } \\
\text { PP1 activity. }\end{array}$ & 67 \\
\hline & $\begin{array}{l}\text { Wild-type and null GM allele } \\
\text { (deletion encompassing 1st } \\
\text { exon encoding PP1) mice } \\
\text { Parent strain: C57BL/6 mice } \\
\text { (examined hind limb muscles) }\end{array}$ & $\begin{array}{c}\text { Adrenaline }(0.5 \mathrm{mg} / \mathrm{g}) \text { for } 15 \\
\mathrm{~min} \text {, insulin }(150 \mathrm{mU} / \mathrm{g}) \text { for } 20 \\
\mathrm{~min} \text { or saline intraperitoneal } \\
\text { injections }\end{array}$ & $\begin{array}{l}\downarrow \text { GS activity } \\
\uparrow \text { GP activity }\end{array}$ & $\begin{array}{c}\text { Adrenaline's effects may be attributed } \\
\text { to decrease in PP1 activity and/or } \\
\text { increase in phosphorylase kinase } \\
\text { activity. }\end{array}$ & 68 \\
\hline Age & $\begin{array}{c}\text { Male Fischer } 344 \text { rats } \\
\text { (examined soleus and tibialis } \\
\text { anterior muscles) }\end{array}$ & $\begin{array}{c}\text { Old ( } 24 \text { months) rats compared } \\
\text { to young ( } 6 \text { months) rats } \\
\text { maintained ad libitum or calorie } \\
\text { restricted }\end{array}$ & $\begin{array}{c}\downarrow \text { GS and GP activity and } \\
\text { GS protein levels (soleus) } \\
\uparrow \text { GS phosphorylation at } \\
\text { Ser640 (soleus) }\end{array}$ & $\begin{array}{l}\text { Aging negatively affects GS and GP } \\
\text { activity in soleus muscle, which may } \\
\text { be associated with impairment of } \\
\text { dephosphorylation of GS at Ser640. }\end{array}$ & 70 \\
\hline Oxidant Stress & $\begin{array}{l}\text { Female lean Zucker rats } \\
\text { (examined soleus muscle) }\end{array}$ & $\begin{array}{c}\text { Isolated muscle from } 9-10 \\
\text { week old rats incubated for } 2 \mathrm{~h} \\
\text { in the absence or presence of } \\
100 \mathrm{mU} / \mathrm{mL} \text { glucose oxidase, } \\
\text { without or with } 5 \mathrm{mU} / \mathrm{ml} \text { insulin. }\end{array}$ & $\begin{array}{l}\downarrow \text { insulin-stimulated GS } \\
\text { activity and glycogen } \\
\text { synthesis }\end{array}$ & $\begin{array}{l}\text { Oxidant stress was found to } \\
\text { be associated with decreased } \\
\text { phosphorylation of insulin receptor, Akt } \\
\text { at Ser473, and GSK-3 } \beta \text { at Ser9. }\end{array}$ & 50 \\
\hline GM null allele & $\begin{array}{l}\text { Wild-type and null GM allele } \\
\text { (deletion encompassing 1st } \\
\text { exon encoding PP1) mice } \\
\text { Parent strain - C57BL/6 mice } \\
\text { (examined hind limb muscles) }\end{array}$ & $\begin{array}{l}\text { Adrenaline }(0.5 \mathrm{mg} / \mathrm{g}) \text { for } \\
15 \mathrm{~min} \text {, insulin }(150 \mathrm{mU} / \mathrm{g}) \\
\text { for } 20 \mathrm{~min} \text {, or saline via } \\
\text { intraperitoneal injection }\end{array}$ & $\begin{array}{l}\downarrow \text { insulin-stimulated GS } \\
\text { activity (null GM mice) } \\
\uparrow \text { GS phosphorylation at } \\
\text { Ser7/640/644 and GP } \\
\text { phosphorylation at Ser14 } \\
\text { (null GM mice) }\end{array}$ & $\begin{array}{l}\text { Decreased PP1 activity allows for } \\
\text { GS and GP phosphorylation which } \\
\text { may also be attributed to increases in } \\
\text { phosphorylase kinase activity. }\end{array}$ & 68 \\
\hline Dexamethasone & $\begin{array}{c}\text { Male Sprague -Dawley rats } \\
\text { (examined gastrocnemius } \\
\text { muscle) }\end{array}$ & $\begin{array}{c}4 \text { groups: saline, } 10 \% \\
\text { sucrose drinking solution, } \\
\text { dexamethasone }(1 \mathrm{mg}), \text { and } \\
\text { dexamethasone+sucrose }-7 \\
\text { days. }\end{array}$ & $\begin{array}{c}\uparrow \text { Glycogen content } \\
\text { (dexamethasone alone) } \\
\downarrow \text { GS activity } \\
\text { (dexamethasone and } \\
\text { dexamethasone+sucrose) }\end{array}$ & $\begin{array}{c}\text { Dexamethasone may regulate GSK-3 } \\
\text { and/or CAMKII activity. }\end{array}$ & 75 \\
\hline
\end{tabular}

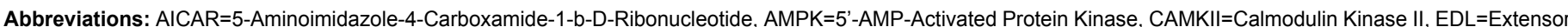
Digitorum Longus, GP=Glycogen Phosphorylase, GS=Glycogen Synthase, mRNA=messenger Ribonucleic Acid, PKA=Protein Kinase A, PMO=Phosphorodiamidate Morpholino Oligonucleotide, PP1=Protein Phosphatase $1, \uparrow=$ significant increases due to factor/manipulation, $\downarrow=$ significant decreases due to factor/manipulation.

$\mathrm{nM}$ ) led to impairment in GS dephosphorylation at Ser640/644 as well as GS fractional activity [65]. However, treatment with AICAR (2 mM) restored the glycogen synthesis and GS activation in the $5 \mathrm{~h}$ insulintreated cells [65].

cAMP pathway: In a study that investigated the effect of adrenaline on insulin-mediated regulation of glucose metabolism in human tibialis anterior muscle found that in the presence of adrenaline (infusion rate of $0.05 \mu \mathrm{g} / \mathrm{kg} / \mathrm{min}$ for $240 \mathrm{~min}$ ), insulin could not activate GS or dephosphorylate GS at Ser641 [66]. The day after adrenaline infusion, an increase in plasma lactate concentration was associated with a decrease in muscle glycogen content [66]. In the soleus muscle of male Wistar rats, it was shown that the insulin-stimulated GSK-3 $\beta$ Ser9 phosphorylation was accompanied by decreases in GS phosphorylation as expected [67]. However, adrenaline $(10 \mu \mathrm{M})$-stimulated GSK$3 \beta$ Ser9 phosphorylation was associated with an increase in GS phosphorylation [67].

The major skeletal muscle glycogen targeting subunit (GM) of PP1 has also been investigated in regards to control by various hormones [68]. $\mathrm{GM}^{-1-}$ mice had increased phosphorylation of GP at Ser14 and GS at Ser7, Ser640, and Ser644 along with a decrease in insulin-stimulated GS activity compared to $\mathrm{GM}^{+/+}$mice [68]. This indicates that the GM subunit of PP1 complex is the major phosphatase complex that leads to the dephosphorylation of these sites in vivo. Adrenaline (0.5 $\mathrm{mg} / \mathrm{g}$ ) treatment for only $15 \mathrm{~min}$ led to a significant increase in GP activity while decreasing GS activity in control mice [68]. However, the same treatment conditions yielded no significant changes in GP or GS activity in $\mathrm{GM}^{-/-}$mice, suggesting that the GM subunit of PP1 is required for adrenaline's actions [68].
Akt pathway: Individuals with T2DM display lower GS activity and increased GS phosphorylation during the recovery period postexercise, which implies these individuals, have impaired response to exercise [30]. Compared to non-diabetic controls, patients with T2DM undergoing a euglycemic-hyperinsulinemic clamp displayed an impairment of the insulin-stimulated glucose disposal and glucose oxidation during euglycemia [69]. This effect was associated with impairment of insulin-stimulated GS activity and decrease of GS dephosphorylation with reduction of Akt phosphorylation at Thr308 and Ser473. During hyperglycemia, the insulin-stimulated glucose disposal and oxidation normalized, however, the dephosphorylation of GS as well as phosphorylation of Akt at Thr308 and Ser473 remained impaired [69]. Women with PCOS have the risk of developing insulin resistance in skeletal muscle. Compared to women without PCOS, women with PCOS display the reduction of insulin-stimulated GS activity and dephosphorylation of GS [57].

\section{Aging}

Aging also seems to play a role in altering GS level and glycogen accumulation. It has been shown that the older rats (24 months) displayed reduced GS and GP activity, lower muscle GS protein levels, and increased phosphorylation of GS in soleus muscle than young mice (6 months) [70]. Along with aging, extended bed rest occurs. One group who investigated the mechanisms behind physical inactivity-induced insulin resistance in the skeletal muscle (vastus lateralis) of 12 healthy male subjects after 7 days of bed rest found that the ability of insulin to activate GS was reduced [71]. They found that phosphorylation of GS at Ser7 and Ser10 increased following bed rest [71]. Interestingly, in rat 
soleus muscle during the basal state, oxidant stress $(100 \mathrm{mU} / \mathrm{mL}$ glucose oxidase) increased GS activity. However, GSK-3 $\beta$ remained active in the presence of both oxidant stress and insulin [50]. The presence of oxidant stress also significantly inhibits the insulin-induced glucose transport and glycogen synthesis [50].

\section{Hormones}

In human muscle cells treated with or without $25 \mathrm{mM}$ glucose for $24 \mathrm{~h}$ in combination with angiotensin $(1 \mu \mathrm{M})$, glucose deprivation plus angiotensin increased levels of ERK $1 \frac{1}{2}$ phosphorylation and GSK-3 $\beta$ (Ser9) phosphorylation [72]. However, only those treated with high glucose and angiotensin displayed an increase in GS phosphorylation at Ser640/641 which correlated with a decrease in GS activity [72].

Glucocorticoids such as dexamethasone have been known to have an impact on glucose and fat metabolism, which could lead to alterations such as insulin resistance and dyslipidemia [73,74]. In the red and white gastrocnemius muscle of rats, the administration of dexamethasone ( $1 \mathrm{mg} / \mathrm{rat} /$ day) increased glycogen concentration while reducing GS activity in both muscle fiber types [75]. Rat treated with dexamethasone and sucrose had decreased muscle glycogen content compared with the dexamethasone alone group. However, this effect was also associated with a decrease in GS activity similar to that seen in animals treated with the dexamethasone alone [75].

\section{Perspectives}

Although the glycogen synthesis pathway has been studied extensively, there seems to be more to be investigated. For example, GSK-3 is known as a major regulator of GS activation through phosphorylation. Using GSK-3 knock-in mice with GSK-3 $\alpha$ and $-\beta$ genes being replaced with mutant forms (GSK-3 $\left.\alpha / \beta^{S 21 A / S 21 A / S 9 A / S 9 A}\right)$, it has been shown that the insulin-mediated inhibition of GSK-3 is not a rate-limiting step in skeletal muscle glycogen synthesis [76]. Even though insulin failed to promote the activation of GS in these GSK$3 \alpha / \beta$ mutant mice, the glycogen content within the skeletal muscle of these mice were similar to their wild-type controls [76].

One determinant of GS activity is the existing amount of glycogen within the muscle as well as muscle fiber type [77,78]. As demonstrated in rodents, low glycogen content was associated with decrease in GS phosphorylation and high glycogen content was associated with decrease in GS activation [79-81]. One group has shown that epinephrine stimulates glycogenolysis in Wistar rat skeletal muscles with normal and high, but not low, glycogen content. The glycogenolysis actually being associated with decreases in GS phosphorylation and increases in GS activity [82]. This demonstrates an association between GS activation and glycogen content in this condition.

Physical activity has also been shown to affect glycogen content in rodents with the phosphorylation of GS being reduced 30 min postexercise, but returning to baseline at 90 min post-exercise [83]. As described previously, physical activity can result in the enhancement of GS activity. On the other hand, it is also well known that during vigorous physical activity, endurance or strength training, the skeletal muscle relies a great deal on the breakdown of glycogen, as well as fat, to provide adequate energy [84]. Besides depletion of muscle glycogen stores, skeletal muscle protein degradation will also occur during such physical activity [85]. The depletion of glycogen will result in the increase of proteolysis to get amino acids and $\beta$-oxidation of fatty acid from muscle fat and reduction of pyruvate oxidation [86]. Therefore, nutritional strategies should be implemented during the post-recovery period to maximize skeletal muscle glycogen and protein synthesis. Besides for the importance of replenishing endogenous substrate stores, optimal nutritional intake can assist in facilitating the repair of damaged muscle [87]. For athletes, nutrition can play a key role in determining the adequate period of time between competitions for complete muscle recovery. Similarly, pre-physical activity nutrition can have a major impact on metabolism and activity during performance [88]. Further research is needed to optimize pre- and post-physical activity nutritional strategies involving the investigation of the regulation of key enzymes in glycogenesis such as GS, GP, and GSK-3.

From a pharmaceutical standpoint, having a greater understanding of the regulation of glycogen synthesis could be beneficial to a number of individuals suffering from a variety of diseases. With the millions of insulin-resistant men and women, the development of glycogen regulating enzyme activators/inhibitors could help alleviate the formation of other conditions such as myopathy. GP inhibitors, for instance, have been receiving attention for being possible therapeutic agents for diabetes and cancer [89]. The regulation of GSK-3 is also a topic of interest among many due to GSK-3 regulation being connected to a number of conditions such Alzheimer's disease, cancer, diabetes, and general muscle wasting $[90,91]$. Therefore, GSK-3 inhibition may provide therapeutic effects to a broad range of conditions.

\section{Conclusion}

The purpose of this review has been to compile relevant research related to the regulation of GS over the past 10 years. As one can tell, there is much still being discovered regarding glucose metabolism in skeletal muscle. More in-depth studies performed both in vitro and in vivo are needed to grasp a full understanding of skeletal muscle GS regulation. With a greater understanding, possible therapeutic benefits could arise for individuals suffering from a variety of metabolic diseases.

\section{Acknowledgement}

The authors thank the Department of Nutrition at the University of Tennessee, Knoxville for financial support to M.G.

\section{References}

1. Roach PJ (2002) Glycogen and its metabolism. Curr Mol Med 2: 101-120.

2. Tirone TA, Brunicardi FC (2001) Overview of glucose regulation. World J Surg 25: $461-467$

3. Zeqiraj E, Sicheri $F$ (2015) Getting a handle on glycogen synthase - Its interaction with glycogenin. Mol Aspects Med 46: 63-69.

4. Hua Q (2010) Insulin: a small protein with a long journey. Protein Cell 1: 537 551.

5. Nordlie RC, Foster JD, Lange AJ (1999) Regulation of glucose production by the liver. Annu Rev Nutr 19: 379-406.

6. Hargreaves M (2004) Muscle glycogen and metabolic regulation. Proc Nutr Soc 63: 217-220.

7. Dashty M (2013) A quick look at biochemistry: carbohydrate metabolism. Clin Biochem 46: 1339-1352.

8. Graham TE, Yuan Z, Hill AK, Wilson RJ (2010) The regulation of muscle glycogen: the granule and its proteins. Acta Physiol (Oxf) 199: 489-498.

9. Palm DC, Rohwer JM, Hofmeyr JH (2013) Regulation of glycogen synthase from mammalian skeletal muscle-a unifying view of allosteric and covalent regulation. FEBS J 280: 2-27.

10. McBride A, Hardie DG (2009) AMP-activated protein kinase--a sensor of glycogen as well as AMP and ATP? Acta Physiol (Oxf) 196: 99-113.

11. Zhang J, Liu $F$ (2014) Tissue-specific insulin signaling in the regulation of metabolism and aging. IUBMB Life 66: 485-495. 
Citation: Goff M, Chen G (2016) Progresses of the Past Decade on Factors Contributing to Skeletal Muscle Glycogen Synthase Regulation Metabolomics 6: 174. doi:10.4172/2153-0769.1000174

12. Bellacosa A, Chan TO, Ahmed NN, Datta K, Malstrom S, et al. (1998) Akt activation by growth factors is a multiple-step process: the role of the $\mathrm{PH}$ domain. Oncogene 17: 313-325.

13. Cohen $P$ (2006) The twentieth century struggle to decipher insulin signalling Nat Rev Mol Cell Biol 7: 867-873.

14. Alessi DR, Cohen $P$ (1998) Mechanism of activation and function of protein kinase B. Curr Opin Genet Dev 8: 55-62.

15. Sarbassov DD, Guertin DA, Ali SM, Sabatini DM (2005) Phosphorylation and regulation of Akt/PKB by the rictor-mTOR complex. Science 307: 1098-1101.

16. Richter EA, Hargreaves M (2013) Exercise, GLUT4, and skeletal muscle glucose uptake. Physiol Rev 93: 993-1017.

17. Cross DA, Alessi DR, Cohen P, Andjelkovich M, Hemmings BA (1995) Inhibition of glycogen synthase kinase-3 by insulin mediated by protein kinase $B$. Nature 378: 785-789.

18. Scott PH, Brunn GJ, Kohn AD, Roth RA, Lawrence JC Jr. (1998) Evidence of insulin-stimulated phosphorylation and activation of the mammalian target of rapamycin mediated by a protein kinase B signaling pathway. Proc Natl Acad Sci USA 95: 7772-7777.

19. Jensen J, Lai YC (2009) Regulation of muscle glycogen synthase phosphorylation and kinetic properties by insulin, exercise, adrenaline and role in insulin resistance. Arch Physiol Biochem 115: 13-21.

20. Newgard CB, Brady MJ, O'Doherty RM, Saltiel AR (2000) Organizing glucose disposal: emerging roles of the glycogen targeting subunits of protein phosphatase-1. Diabetes 49: 1967-1977.

21. Shpakov AO, Derkach KV (2013) The functional state of hormone-sensitive adenylyl cyclase signaling system in diabetes mellitus. J Signal Transduct 2013: 594213.

22. Taylor SS, Zhang P, Steichen JM, Keshwani MM, Kornev AP (2013) PKA lessons learned after twenty years. Biochim Biophys Acta 1834: 1271-1278.

23. Brushia RJ, Walsh DA (1999) Phosphorylase kinase: the complexity of its regulation is reflected in the complexity of its structure. Front Biosci 4: D618641.

24. Zhang T, Wang S, Lin Y, Xu W, Ye D, et al. (2012) Acetylation negatively regulates glycogen phosphorylase by recruiting protein phosphatase 1 . Cell Metab 15: 75-87.

25. Proud CG, Rylatt DB, Yeaman SJ, Cohen P (1977) Amino acid sequences at the two sites on glycogen synthetase phosphorylated by cyclic AMP-dependent protein kinase and their dephosphorylation by protein phosphatase-III. FEBS letters 80: 435-442.

26. Rajas F, Labrune P, Mithieux G (2013) Glycogen storage disease type 1 and diabetes: learning by comparing and contrasting the two disorders. Diabetes Metab 39: 377-387.

27. Stalmans W, Bollen M, Mvumbi L (1987) Control of glycogen synthesis in health and disease. Diabetes Metab Rev 3: 127-161.

28. Ryan AS, Katzel LI, Prior SJ, McLenithan JC, Goldberg AP, et al. (2014) Aerobic exercises plus weight loss improves insulin sensitivity and increases skeletal muscle glycogen synthase activity in older men. J Gerontol A Biol Sci Med Sci 69: 790-798

29. Lai YC, Zarrinpashneh E, Jensen J (2010) Additive effect of contraction and insulin on glucose uptake and glycogen synthase in muscle with different glycogen contents. J Appl Physiol (1985) 108: 1106-1115.

30. Pedersen AJ, Hingst JR, Friedrichsen M, Kristensen JM, Højlund K, et al. (2015) Dysregulation of muscle glycogen synthase in recovery from exercise in type 2 diabetes. Diabetologia 58: 1569-1578.

31. Jensen J, Tantiwong P, Stuenæs JT, Molina-Carrion M, DeFronzo RA, et al. (2012) Effect of acute exercise on glycogen synthase in muscle from obese and diabetic subjects. Am J Physiol Endocrinol Metab 303: E82-89.

32. Vind BF, Pehmøller C, Treebak JT, Birk JB, Hey-Mogensen M, et al. (2011) Impaired insulin-induced site-specific phosphorylation of TBC1 domain family, member 4 (TBC1D4) in skeletal muscle of type 2 diabetes patients is restored by endurance exercise-training. Diabetologia 54: 157-167.

33. Bienso RS, Olesen J, Gliemann L, Schmidt JF, Matzen MS et al. (2015) Effects of Exercise Training on Regulation of Skeletal Muscle Glucose Metabolism in Elderly Men. The journals of gerontology 70 : 866-872.
34. Vigelso A, Prats C, Ploug T, Dela F, Helge JW (2015) Higher muscle content of perilipin 5 and endothelial lipase protein in trained than untrained middle-aged men. Physiol Res.

35. Ryan AS, Ortmeyer HK, Sorkin JD (2012) Exercise with calorie restriction improves insulin sensitivity and glycogen synthase activity in obese postmenopausal women with impaired glucose tolerance. Am J Physio Endocrinol Metab 302: 145-152.

36. Manabe Y, Gollisch KS, Holton L, Kim YB, Brandauer J, et al. (2013) Exercise training-induced adaptations associated with increases in skeletal muscle glycogen content. FEBS J 280: 916-926.

37. Irimia JM, Rovira J, Nielsen JN, Guerrero M, Wojtaszewski JF, et al. (2012) Hexokinase 2, glycogen synthase and phosphorylase play a key role in muscle glycogen super compensation. PLoS One 7: e42453.

38. Kim YB, Peroni OD, Aschenbach WG, Minokoshi Y, Kotani K et al. (2005) Muscle-specific deletion of the Glut4 glucose transporter alters multiple regulatory steps in glycogen metabolism. Mol Cell Biol 25: 9713-9723.

39. Yu H, Hirshman MF, Fujii N, Pomerleau JM, Peter LE, et al. (2006) Musclespecific overexpression of wild type and R225Q mutant AMP-activated protein kinase gamma3-subunit differentially regulates glycogen accumulation. Am J Physiol Endocrinol Metab 291: 557-565.

40. Barre L, Richardson C, Hirshman MF, Brozinick J, Fieringet S et al. (2007) Genetic model for the chronic activation of skeletal muscle AMP-activated protein kinase leads to glycogen accumulation. Am J Physiol Endocrinol Metab 292: 802-811.

41. Ciaraldi TP, Nikoulina SE, Bandukwala RA, Carter L, Henry RR (2007) Role of glycogen synthase kinase- 3 alpha in insulin action in cultured human skeletal muscle cells. Endocrinology 148: 4393-4399.

42. Friedrichsen M, Birk JB, Richter EA, Madsen RR, Pehmoller C et al. (2013) Akt2 influences glycogen synthase activity in human skeletal muscle through regulation of $\mathrm{NH}(2)$-terminal (sites $2+2 a$ ) phosphorylation. Am J Physiol Endocrinol Metab 304 : 631-639.

43. Ciaraldi TP, Carter L, Mudaliar S, Henry RR (2010) GSK-3beta and control of glucose metabolism and insulin action in human skeletal muscle. Mol Cell Endocrinol 315: 153-158.

44. Taylor KM, Meyers E, Phipps M, Kishnani PS, Cheng SH, et al. (2013) Dysregulation of multiple facets of glycogen metabolism in a murine model of Pompe disease. PLoS One 8: e56181.

45. Ashe KM, Taylor KM, Chu Q, Meyers E, Ellis A, et al. (2010) Inhibition of glycogen biosynthesis via mTORC1 suppression as an adjunct therapy for Pompe disease. Mol Genet Metab 100: 309-315

46. Reihmane D, Dela F (2014) Interleukin-6: possible biological roles during exercise. Eur J Sport Sci 14: 242-250.

47. Al-Khalili L, Bouzakri K, Glund S, Lönnqvist F, Koistinen HA, et al. (2006) Signaling specificity of interleukin- 6 action on glucose and lipid metabolism in skeletal muscle. Mol Endocrinol 20: 3364-3375.

48. Hojlund K, Frystyk J, Levin K, Flyvbjerg A, Wojtaszewski JF, et al. (2006) Reduced plasma adiponectin concentrations may contribute to impaired insulin activation of glycogen synthase in skeletal muscle of patients with type 2 diabetes. Diabetologia 49: 1283-1291.

49. Xiong Q, Deng CY, Chai J, Jiang SW, Xiong YZ, et al. (2009) Knockdown of endogenous SKIP gene enhanced insulin-induced glycogen synthesis signaling in differentiating C2C12 myoblasts. BMB Rep 42: 119-124.

50. Dokken BB, Saengsirisuwan V, Kim JS, Teachey MK, Henriksen EJ (2008) Oxidative stress-induced insulin resistance in rat skeletal muscle: role of glycogen synthase kinase-3. Am J Physiol Endocrinol Metab 294: E615-621.

51. Iwasaki H, Naka A, lida KT, Nakagawa Y, Matsuzaka T, et al. (2012) TFE3 regulates muscle metabolic gene expression, increases glycogen stores, and enhances insulin sensitivity in mice. Am J Physiol Endocrinol Metab 302: E896902

52. Kanda A, Morifuji M, Fukasawa T, Koga J, Kanegae M, et al. (2012) Dietary whey protein hydrolysates increase skeletal muscle glycogen levels via activation of glycogen synthase in mice. J Agric Food Chem 60: 11403-11408.

53. Taylor AJ, Ye JM, Schmitz-Peiffer C (2006) Inhibition of glycogen synthesis by increased lipid availability is associated with subcellular redistribution of glycogen synthase. J Endocrinol 188: 11-23. 
Citation: Goff M, Chen G (2016) Progresses of the Past Decade on Factors Contributing to Skeletal Muscle Glycogen Synthase Regulation. Metabolomics 6: 174. doi:10.4172/2153-0769.1000174

Page 11 of 11

54. Gao D, Li Q, LiY, Liu Z, Fan Y, et al. (2009) Antidiabetic and antioxidant effects of oleanolic acid from Ligustrum lucidum Ait in alloxan-induced diabetic rats. Phytother Res 23: 1257-1262.

55. Wang X, Li YL, Wu H, Liu JZ, Hu JX, et al. (2011) Antidiabetic effect of oleanolic acid: a promising use of a traditional pharmacological agent. Phytother Res 25 : 1031-1040.

56. Mukundwa A, Mukaratirwa S, Masola B (2016) Effects of oleanolic acid on the insulin signaling pathway in skeletal muscle of streptozotocin-induced diabetic male Sprague-Dawley rats. J Diabetes 8: 98-108.

57. Glintborg D, Højlund K, Andersen NR, Hansen BF, Beck-Nielsen H, et al. (2008) Impaired insulin activation and dephosphorylation of glycogen synthase in skeletal muscle of women with polycystic ovary syndrome is reversed by pioglitazone treatment. J Clin Endocrinol Metab 93: 3618-3626.

58. Savage DB, Zhai L, Ravikumar B, Choi CS, Snaar JE, et al. (2008) A prevalent variant in PPP1R3A impairs glycogen synthesis and reduces muscle glycogen content in humans and mice. PLoS Med 5: e27.

59. Dasouki M, Jawdat O, Almadhoun O, Pasnoor M, McVey AL, et al. (2014) Pompe disease: literature review and case series. Neurol Clin 32: 751-776, ix.

60. Hicks J, Wartchow E, Mierau G (2011) Glycogen storage diseases: a brief review and update on clinical features, genetic abnormalities, pathologic features, and treatment. Ultrastruct Pathol 35: 183-196.

61. Clayton NP, Nelson CA, Weeden T, Taylor KM, Morelandet RJ et al. (2014) Antisense Oligonucleotide-mediated Suppression of Muscle Glycogen Synthase 1 Synthesis as an Approach for Substrate Reduction Therapy of Pompe Disease. Molecular therapy- Nucleic acids 3: 206

62. Miyamoto L, Toyoda T, Hayashi T, Yonemitsu S, Nakano M, et al. (2007) Effect of acute activation of 5'-AMP-activated protein kinase on glycogen regulation in isolated rat skeletal muscle. J Appl Physiol 102: 1007-1013.

63. Fediuc S, Gaidhu MP, Ceddia RB (2006) Inhibition of insulin-stimulated glycogen synthesis by 5-aminoimidasole-4-carboxamide-1-beta-d-ribofuranosideinduced adenosine 5'-monophosphate-activated protein kinase activation: interactions with Akt, glycogen synthase kinase 3-3alpha/beta, and glycogen synthase in isolated rat soleus muscle. Endocrinology 147: 5170-5177.

64. Hunter RW, Treebak JT, Wojtaszewski JF, Sakamoto K (2011) Molecula mechanism by which AMP-activated protein kinase activation promotes glycogen accumulation in muscle. Diabetes 60: 766-774.

65. Litherland GJ, Morris NJ, Walker M, Yeaman SJ (2007) Role of glycogen content in insulin resistance in human muscle cells. J Cell Physiol 211: 344 352.

66. Jensen J, Ruge T, Lai YC, Svensson MK, Eriksson JW (2011) Effects of adrenaline on whole-body glucose metabolism and insulin-mediated regulation of glycogen synthase and PKB phosphorylation in human skeletal muscle. Metabolism 60: 215-226.

67. Jensen J, Brennesvik EO, Lai YC, Shepherd PR (2007) GSK-3beta regulation in skeletal muscles by adrenaline and insulin: evidence that PKA and PKB regulate different pools of GSK-3. Cell Signal 19: 204-210.

68. Toole BJ, Cohen PT (2007). The skeletal muscle-specific glycogen-targeted protein phosphatase 1 plays a major role in the regulation of glycogen metabolism by adrenaline in vivo. Cell Signal 19: 1044-1055.

69. Vind BF, Birk JB, Vienberg SG, Andersen B, Beck-Nielsen H, et al. (2012) Hyperglycaemia normalises insulin action on glucose metabolism but not the impaired activation of AKT and glycogen synthase in the skeletal muscle of patients with type 2 diabetes. Diabetologia 55: 1435-1445.

70. Montori-Grau M, Minor R, Lerin C, Allard J, Garcia-Martinez C, et al. (2009) Effects of aging and calorie restriction on rat skeletal muscle glycogen synthase and glycogen phosphorylase. Exp Gerontol 44: 426-433.

71. Biens $\varnothing$ RS, Ringholm S, Kiilerich K, Aachmann-Andersen NJ, Krogh-Madsen R, et al. (2012) GLUT4 and glycogen synthase are key players in bed restinduced insulin resistance. Diabetes 61: 1090-1099.

72. Montori-Grau M, Tarrats N, Osorio-Conles O, Orozco A, Marco LS, et al. (2013) Glucose dependence of glycogen synthase activity regulation by GSK3 and MEK/ERK inhibitors and angiotensin-(1-7) action on these pathways in cultured human myotubes. Cell Signal 25: 1318-1327.

73. Schäcke H, Döcke WD, Asadullah K (2002) Mechanisms involved in the side effects of glucocorticoids. Pharmacol Ther 96: 23-43.
74. Isomaa $B$, Henricsson M, Almgren P, Tuomi T, Taskinen MR, et al. (2001) The metabolic syndrome influences the risk of chronic complications in patients with type II diabetes. Diabetologia 44: 1148-1154.

75. Coderre L, Vallega GA, Pilch PF, Chipkin SR (2007) Regulation of glycogen concentration and glycogen synthase activity in skeletal muscle of insulinresistant rats. Arch Biochem Biophys 464: 144-150.

76. Bouskila M, Hirshman MF, Jensen J, Goodyear LJ, Sakamoto K (2008) Insulin promotes glycogen synthesis in the absence of GSK3 phosphorylation in skeletal muscle. Am J Physiol Endocrinol Metab 294: E28-35.

77. Raja G, Brau L, Palmer TN, Fournier PA (2008) Fiber-specific responses of muscle glycogen repletion in fasted rats physically active during recovery from high-intensity physical exertion. American journal of physiology. Regulatory, integrative and comparative physiology 295: 633-641.

78. Murphy RM, Xu H, Latchman H, Larkins NT, Gooley PR, et al. (2012) Single fiber analyses of glycogen-related proteins reveal their differential association with glycogen in rat skeletal muscle. Am J Physiol Cell Physiol 303: 1146-1155.

79. Lai YC, Stuenaes JT, Kuo CH, Jensen J (2007) Glycogen content and contraction regulate glycogen synthase phosphorylation and affinity for UDPglucose in rat skeletal muscles. Am J Physiol Endocrinol Metab 293: 16221629.

80. Lai YC, Lin FC, Jensen J (2009) Glycogen content regulates insulin- but not contraction-mediated glycogen synthase activation in the rat slow-twitch soleus muscles. Acta Physiol (Oxf) 197: 139-150

81. Jensen J, Jebens E, Brennesvik EO, Ruzzin J, Soos MA, et al. (2006) Muscle glycogen inharmoniously regulates glycogen synthase activity, glucose uptake, and proximal insulin signaling. Am J Physiol Endocrinol Metab 290: E154$154 \mathrm{E} 162$.

82. Kolnes AJ, Birk JB, Eilertsen E, Stuenaes JT, Wojtaszewski JF, et al. (2015) Epinephrine-stimulated glycogen breakdown activates glycogen synthase and increases insulin-stimulated glucose uptake in epitrochlearis muscles. Am J Physiol Endocrinol Metab 308: 231-240

83. Hara D, Morrison PJ, Ding Z, Ivy JL (2011) Effect of carbohydrate-protein supplementation post exercise on rat muscle glycogen synthesis and phosphorylation of proteins controlling glucose storage. Metabolism 60: 14061415.

84. Hargreaves M (2015) Exercise, muscle, and CHO metabolism. Scand J Med Sci Sports 25 Suppl 4: 29-33.

85. Pasiakos SM, Carbone JW (2014) Assessment of skeletal muscle proteolysis and the regulatory response to nutrition and exercise. IUBMB Life 66: 478-484

86. Blomstrand E, Saltin B (1999) Effect of muscle glycogen on glucose, lactate and amino acid metabolism during exercise and recovery in human subjects. $J$ Physiol 514: 293-302.

87. Domingues-Faria C, Vasson MP, Goncalves-Mendes N, Boirie Y, Walrand S (2016) Skeletal muscle regeneration and impact of aging and nutrition. Ageing Res Rev 26: 22-36.

88. Ormsbee MJ, Bach CW, Baur DA (2014) Pre-exercise nutrition: the role of macronutrients, modified starches and supplements on metabolism and endurance performance. Nutrients 6: 1782-1808.

89. Gaboriaud-Kolar N, Skaltsounis AL (2013) Glycogen phosphorylase inhibitors a patent review (2008-2012). Expert Opin Ther Pat 23: 1017-1032.

90. Jope RS, Yuskaitis CJ, Beurel E (2007) Glycogen synthase kinase-3 (GSK3): inflammation, diseases, and therapeutics. Neurochem Res 32: 577-595.

91. Verhees KJ, Pansters NA, Schols AM, Langen RC (2013) Regulation of

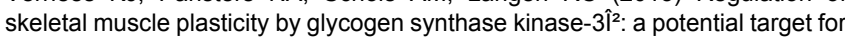
the treatment of muscle wasting. Curr Pharm Des 19: 3276-3298. 